\title{
ALTERNATIVE DESIGN OF THE BUILDING STRUCTURE OF STEEL FRAME BRIDGE TYPE STEEL ARCH WITH WARREN FRAME IN TUKAD BANGKUNG BRIDGE IN BADUNG - BALI
}

\author{
Sudirman Indra ${ }^{1 *}$, Mohammad Erfan ${ }^{2}$, I Komang Dedi Wijaya ${ }^{3}$ \\ 1,2,3 Department of Civil Engineering, National Institute of Technology, Malang, Indonesia
}

*Corresponding Email: dirman.indra@lecturer.itn.ac.id

\begin{abstract}
In planning and designing a bridge it should consider the function of transportation needs, technical and architectural-aesthetic requirements which include: Traffic aspects, Technical aspects, Aesthetic aspects. the alternative bridge design structure of the steel arch bridge-type steel frame with warren frame on the Tukad Bridge in Bangkung district. Badung - Bali is a steel frame bridge that has an overall span of $360 \mathrm{~m}$ and $9.6 \mathrm{~m}$ wide. alternative upper structure at the Tukad Bangkung bridge Badung Regency - Bali with the merging of the steel arch construction of 2 roller joints and the warren frame structure. Where between the curve/arc with a steel profile plate connected by a cable that serves to provide strong support to the frame structure because of the long stretch. In the planning of the bridge this time using the L.R.F.D method and for the structural analysis modeling the writer uses the STAADPRO V8i assistive program. From the analysis of the results of the calculation of the structure above obtained planning dimensions of the Steel Arch bridge that is planned to use a steel profile, WF $350 \times 175 \times 7 \times 11$ for gel. elongated, WF $918 \times 303 \times 19 \times 37$ for gel. transversely, WF $350 \times 350 \times 12 \times 9$ for gel. transversely above, WF 498 x 432 x 45 x 70 for gel. parent, LD 250,250.25 for wind bonds.
\end{abstract}

Keywords: Bridge, Steel Frame, Pennsylvania Petit Truss, LRFD.

\section{Introduction}

The type of a bridge must observe to several factors which include the length and span of the load that must be borne and the selection of appropriate technology. But the overall economic planning result is not only determined by the choice of bridge type but also depends on each detail of the upper structure and the lower structure of the bridge itself.

The existing bridge was built with the PreBridged Bridge, the author wants to provide an alternative structure on the bridge Tukad Bangkung Badung Regency - Bali with the merger of steel arch construction 2 steel roller joints and warren frame structure. Where between the curve / arc with a steel profile plate connected by a cable that serves to provide strength support to the frame structure because of the long stretch. Where between the curve / arc with a steel profile plate connected by a cable that serves to provide strength support to the frame structure because of the long stretch.

The reasons for using the steel components above are because:

- The steel construction used is the result of fabrication with standards that have been adapted to span the bridge to speed up the implementation process in the field.

- The bridge components, if not used again, still have a sale value (economic value) as scrap metal.

- Does not require a large space at the time of implementation.

\section{Bridge Structuring Elements}

\subsection{Steel Arch Planning Theory}

The basic principle in planning this arc bridge is that the workload from the vehicle floor is diverted to the suspension cable which is then routed to the knot plate $[1,2,3]$. The forces that work will then be distributed and accepted by each trunk in the form of compressive forces or pull bars. For the steel arch bridge construction section (Steel Arch) can be seen in Figure 1. 

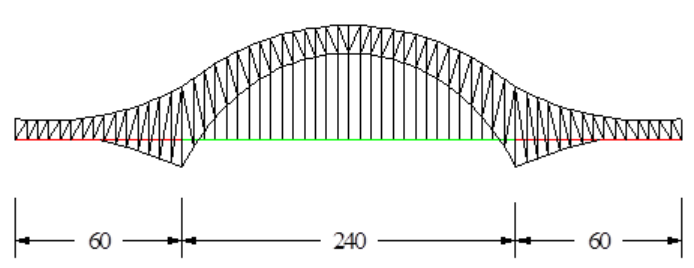

Figure 1 Structure of Steel Curved Bridge Construction

To get a good shape, where the vehicle floor is under an arc, the following equation must be met:

$$
\begin{gathered}
f=\left(\frac{1}{5}-\frac{1}{8}\right) L \\
h=\left(\frac{1}{25}-\frac{1}{45}\right) L \\
H=\left(\frac{1}{12} L\right)
\end{gathered}
$$

where:

$f \quad$ : maximum height of the bridge arc

$h$ : distance between the lower arc and the upper arc of the complement

$H$ : distance / height between the bridge's arc wings

While determining the height of each vertical bar in each panel uses the parabolic formula as follows:

$$
y=\frac{4 \cdot f \cdot x(L-x)}{L^{2}}
$$

For more details can be seen in Figure 2.

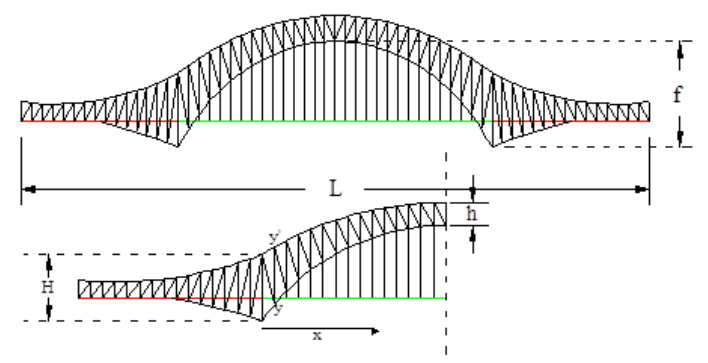

Figure 2 Schematic Height Planning Schemes

Based on these equations, the vertical bar will reach the highest height in the middle of the bridge.

\subsection{Bolt Connection}

In the planning of this steel arch bridge, the connection is planned to use A325 high quality bolts on the profile connection. A325 bolts are made of medium carbon steel with heat treatment which has a melting strength of around 500-630 Mpa.

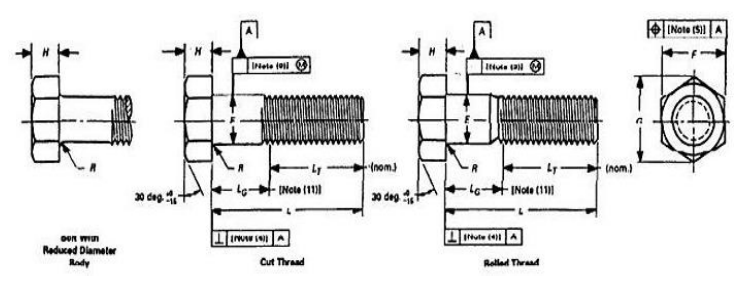

Figure 3 A325 Bolt Specifications

\subsection{Socket (Open Wire Rope Sockets)}

In this steel arch bridge planning, the connection between the hanger cable / hanger is used, namely open wire rope sockets. The socket is designed based on the strength of the cable permit, which serves to hold the pull of the cable to the main structure and stiffen girder.
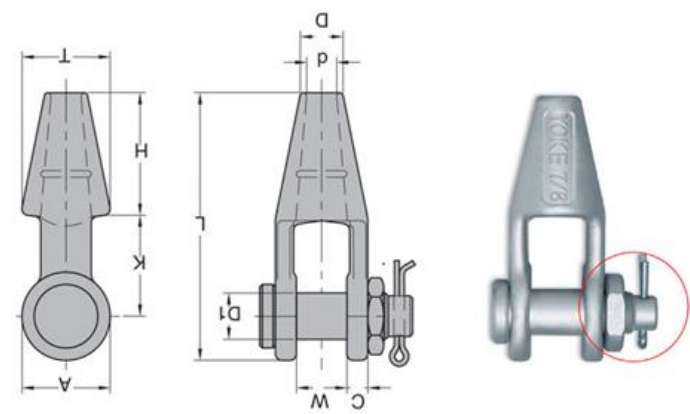

Figure 4 Open Wire Rope Sockets

\subsection{Cable}

The cable in the planning of the arc frame bridge functions as a hanging rod which is also a pull rod. According to the shape of this cable can be divided into two parts, namely wire ropes and parallel wire cables. To prevent rust, the wire is coated (galvanized) which serves to protect the wire against external influences. The cable is also tightly wrapped. The wrapper serves to hold water or water vapor, as well as a fuse for cables (Parallel wire cables).

Important differences between the two cable types are:

- With the same diameter Parallel wire cables are stronger than wire roper.

- Modulus of elasticity Parallel wire cables are greater than wire roper, usually used for bridges with shorter spans, whereas for Parallel wire cables can be used in all spans.

Control of a cable whether safe or not against the axial forces that work is to see how much tension / breaking strength where the magnitude 
of the diameter taken. So, the axial force that occurs must be smaller than the existing breaking strength.

\subsubsection{Wire Roper}

Each rope consists of 7 strands and each strand contains $7,19,37$ or 61 wires. The wires are woven to get a strand, then the strands are woven to make a rope. Each rope must not have more than 250-300 wire, it is intended to avoid being too rigid, so that the installation time is not too difficult.

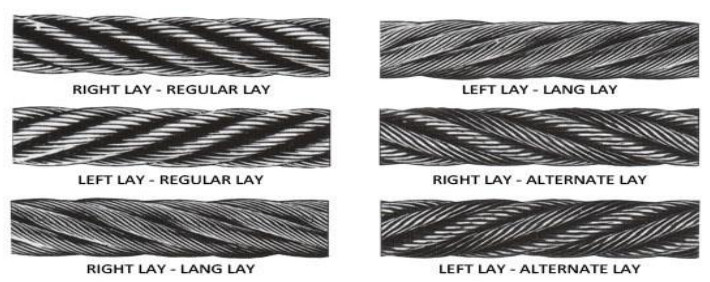

Figure 5 Wire Rope Cable

\subsubsection{Wire Roper}

For this type, approximately 250-350 wires that are parallel to each other constitute a strand. A cable can consist of 7, 19, 37 or 61 strands that are joined together.

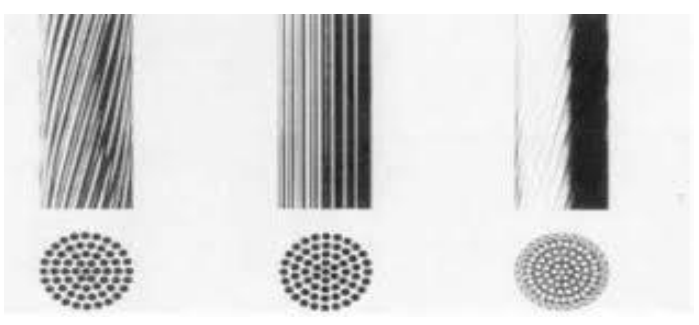

Figure 6 Parallel Wire Cable

\subsection{Cable Control and Cable Dimensions}

To determine the dimensions of the hanger cable / hanger we must know the breaking strength / breaking strength (breaking strength) that occurs in the cable. This breaking strength can be seen in the Cable Roof Structures table listed in the appendix. For cable control, it can be seen in the STAAD PRO output. The results of the static calculation at the output of STAAD PRO show that the tensile forces that occur cannot exceed the breaking strength / breaking strength of the hanger / hanger cable.

\subsection{Indonesian National Standard (SNI) Rules used}

In accordance with the Standard National Indonesia, which is used as reference planning in here are technical regulations or technical standards of Indonesia to make Detail Engineering Design (DED) Bridge Steel Arch Design in Badung - Bali [1,2,3,4,5,6], among others:

1. SNI 1725:2016 Standard for Loading Planning on Bridges.

2. RSNI-T-03-2005 Planning of Steel Structures for bridges.

3. RSNI-T-12-2004 Concrete Structure Planning for Bridges.

4. RSNI-T-1729-2015 Specifications for Structural Steel Buildings.

5. The LRFD (Load and Resistance Factor Design) method, used in steel planning and calculation includes the planning of tensile rods, compressive rods and joint connections.

6. Analysis of Steel Arch type bridge structure in 3-d calculations using STAAD PRO V8i.

\section{Planning Analysis}

\subsection{Planning Data (Bridge General Data)}

1. Structure Name : Bangkuk Tukad Bridge

2. Location : Plaga Village, Petang

District, Badung Regency, Bali, Indonesia

3. Building function : Bridge

4. Building length : 360 meters

5. Bridge width : 9.6 meters

\subsection{Planning Data (Bridge General Data)}

In planning this bridge an approach to the case study is used, with the calculation data using the Load Resistance Factor and Design (LRFD) method $[5,7,8]$.

\subsection{Existing Data of Tukad Bngkung Bridge}

1. Bridge Class : 1 (one)

2. Bridge length $: 360$ meters

3. Bridge width : 9.6 meters

4. Type Bridge : Prestressed Concrete Precast Segmental Cantilever

\subsection{Place of Planning}


Tukad Bangkung Bridge is located in Plaga Village, Petang District, Badung Regency, Bali, Indonesia.

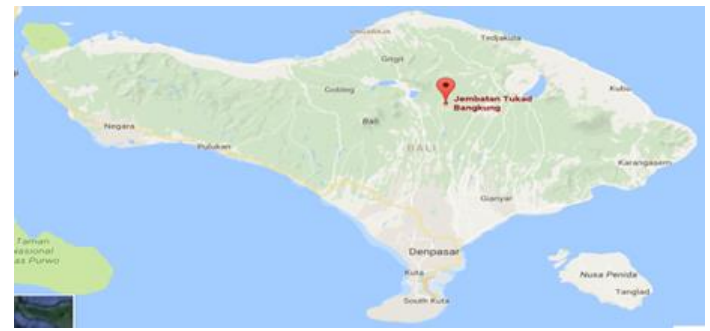

Figure 7 Location Map of Tukad Bangkung Bridge

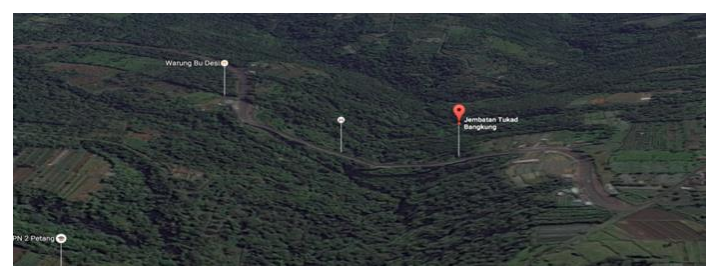

Figure 8 Detail Map Location of Bangkung Tukad Bridge

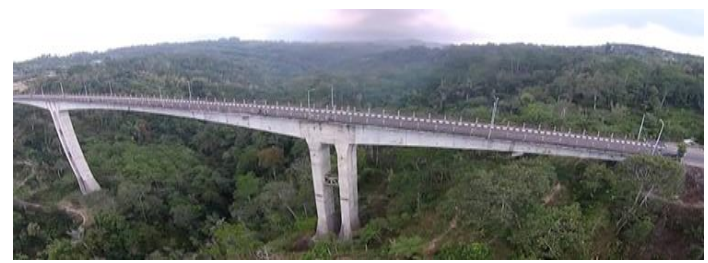

Figure 9 Existing Tukad Bangkung Bridge

\section{Results and Discussion}

\subsection{Existing Data of Tukad Bngkung Bridge}

1. Bridge Class : 1 (one)

2. Bridge length $: 360$ meters

3. Bridge width : 9.6 meters

4. Type Bridge : Prestressed Concrete Precast Segmental Cantilever

\subsection{Existing Data of Tukad Bngkung Bridge}

1. Bridge Class : 1 (one)

2. Bridge Length : 360 meters
3. Vehicle Floor Width : 9.6 meters

4. Width of Sidewalks : 2 × 0.8 meters

5. Bridge Type : Arch Steel Frame

6. Distance between transverse girders: 5 meters

7. Distance between lengthwise girders: 1.6 meters

8. Concrete plate thickness: 0.2 meters

9. Quality of reinforcing steel $(f y): 390 \mathrm{MPa}$

10. Concrete Quality $\left(f c^{\prime}\right): 35 \mathrm{MPa}$

11. Steel quality : BJ 52

- Steel melting strength: $3600 \mathrm{~kg} / \mathrm{cm}^{2}$

- Base strength : $2400 \mathrm{~kg} / \mathrm{cm}^{2}$

\subsection{Loading Data}

a. Asphalt layer of vehicle floor

- Asphalt thickness : 0.05 meter

- Specific gravity of asphalt: $2,245 \mathrm{~kg} / \mathrm{m}^{3}$

- $\mathrm{Ku}_{\mathrm{MS}}$ load factor: 1.3 (concrete cast in place)

b. Plate concrete floor footpath

- Thickness of concrete plate : 0.55 meters

- Tiles: 0.05 meters

- Specific gravity of reinforced concrete: $2400 \mathrm{~kg} / \mathrm{m}^{3}$

- $\mathrm{Ku}_{\mathrm{MS}}$ load factor: 1.3 (concrete cast in place)

c. Asphalt layer of vehicle floor

- Thickness of concrete plate : 0.2 meters

- Specific gravity of reinforced concrete: $2,400 \mathrm{~kg} / \mathrm{m} 3$

- KuMS load factor: 1.3 (concrete cast in place)

d. Rainwater

- Rainwater thickness : 0.05 meter

- Specific gravity of rainwater: $1,000 \mathrm{~kg} / \mathrm{m}^{3}$

- $\mathrm{Ku}_{\mathrm{MS}}$ load factor: 2 (concrete cast in place)

e. Steel Deck

- Thick steel deck : $4.55 \mathrm{~mm}$

- Heavy steel deck : $56.15 \mathrm{~kg} / \mathrm{m}^{2}$

- $\mathrm{Ku}_{\mathrm{MS}}$ load factor: 1.1 (concrete cast in place)

\subsection{Calculation of Statics to Load Off and Load Life}

For statics calculations use the Staad Pro V8i program. The loading conditions are taken in extreme conditions where: 


$$
\begin{aligned}
& \mathrm{Qu}=2935,56 \mathrm{~kg} / \mathrm{m} \\
& \mathrm{Qu} 2=1500 \mathrm{~kg} / \mathrm{m} \\
& \mathrm{Qd} 1=1097,76 \mathrm{~kg} / \mathrm{m} \\
& \mathrm{Tu}=22500 \mathrm{~kg}
\end{aligned}
$$

Then obtained reinforcement: Used reinforcement support/m' Used reinforcement support $/ \mathrm{m}$ ' Reinforcement for retrieved Steel Deck Plate

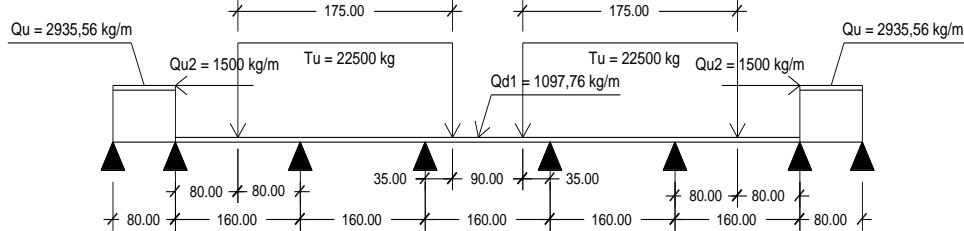

$=\mathrm{D} 13-120 \mathrm{~mm}$

$=\mathrm{D} 13-120 \mathrm{~mm}$

$=\mathrm{D} 13-250 \mathrm{~mm}$

$=$ Type $1000 \mathrm{~mm}$

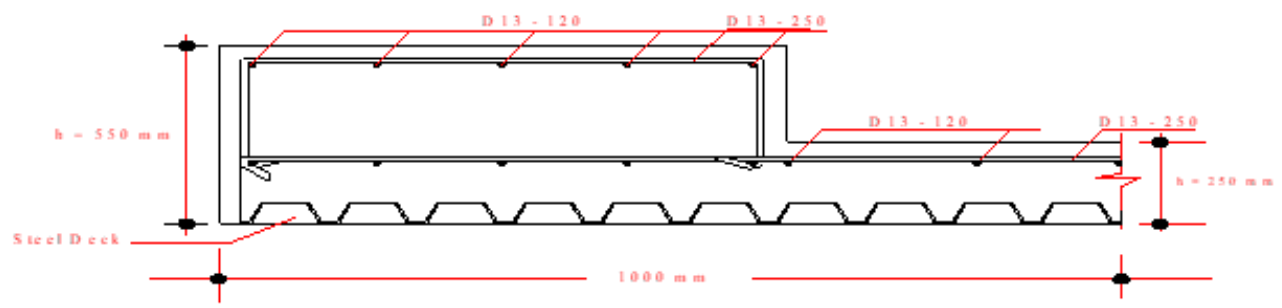

Figure 10 Picture of Vehicle Floor Plate Repair

\subsection{Elongated Girder Planning}

- Elongated girder distance $\quad: 1.6$ meters

- Distance of transverse girder : 4.0 meters Load calculation

Obtained moment of greatest on the girder middle of 7,740.70 kg.m

Then, the WF profile is used. $350 \times 175 \times 7 \times 11$ Control: $\phi \mathrm{Mn} \geq \mathrm{Mu}$

$$
78,382.15 \text { kg.m } \geq 7740.70 \text { kg.m ...... Ok }
$$

\subsection{Transverse Girder Planning}

- Elongated girder distance : 1.6 meters

- Distance of transverse girder : 4.0 meters Load calculation

Obtained moment of greatest on the girder middle of $510,318.799 \mathrm{~kg} . \mathrm{m}$

Then, the WF profile is used. $918 \times 303 \times 19 \times 37$ Control: $\phi \mathrm{Mn} \geq \mathrm{Mu}$

$560,818.81$ kg.m $\geq 510,318.799$ kg.m...Ok

\subsection{Master Girder Planning}

Load calculation

- Obtained axial force factor on rod no. 454 (Vertical Compressive Rod) $\mathrm{Pu}=1267570 \mathrm{~kg}$

Control: $\mathrm{P}_{\mathrm{n}} \geq \mathrm{P}_{\mathrm{u}}$ $3628,929 \times 770,10=2375442,489 \mathrm{~kg}$

$2794638,223 \mathrm{~kg} \geq 1267570 \mathrm{~kg}$...... (Secure)

- Obtained axial force factor on rod no 2317
(Pull Rod)

$\mathrm{T}_{\mathrm{u}}=205,4420 \mathrm{~kg}$

Then the WF profile is used:

$498 \times 432 \times 45 \times 70$

Control: $\varphi t$. $\mathrm{Tn}=0.75$. Fu Ac $\geq \mathrm{Tu}$

$263,0211.375 \geq 2,054,420 \mathrm{~kg}$...... (Secure)

\subsection{Cable Planning and Cable Dimensions}

To determine the dimensions of the cable hanger, we must know the breaking strength that occurs in the cable. This breaking strength can be seen in the Technical Data for The VSL Post Tensioning System table listed in the appendix.

For cable control can be seen on the STAAD PRO V8i output. The results of the static calculation on the output of the STAAD PRO V8i obtained breaking forces that occur, where the tensile forces that occur cannot exceed the breaking strength / breaking strength on the hanger cable. In the design of STAAD PRO V8i for cable properties used Type CH406.4x12 which has an area of $178.59 \mathrm{~mm} 2$. From the results of STAAD PRO V8i output, the maximum breaking strength of cable $=940,273 \mathrm{kN}$ on the rod 1422. Tendon Y1860S7 cable is used with an area of $150 \mathrm{~mm}^{2}$ (4 strands number) cable then: Wide area CH406.4x12 $\geq$ Tendon Y1860S7

$178,59 \mathrm{~mm}^{2} \geq 150 \mathrm{~mm}^{2} \ldots \ldots$ (Fulfill)

Breaking strength Tendon Y1860S7 (4 Strands) = $1116 \mathrm{kN}$ 
Breaking strength > Maximum breaking strength of the cable

$\rightarrow \quad 1116 \mathrm{kN}>940,273 \mathrm{kN} \ldots \ldots .($ secure cable)

\section{Conclusion}

From the results of planning and analysis in the previous chapter, the following conclusions can be drawn:

1. On vehicle floor plate planning:

- Concrete plate tabs: $250 \mathrm{~mm}$

- Principal reinforcement used: D13 - $250 \mathrm{~mm}$

- Used reinforcement for: $\phi 13$ - $250 \mathrm{~mm}$

2. In planning the girder extends:

- Profile used: WF 350 X 175 X 7 X 11

3. In planning the transverse girder below:

- Profile used: WF 918 X 303 X 19 X 37

4. In planning the transverse girder above the middle:

- Profile used: WF 350 x 350 x 12 × 9

5. In planning the transverse girder over the edge:

- Profile used: WF 350 x 350 x 12 x 9

6. In planning the girder:

- Profile used: WF 498 x 432 x 45 x 70

7. On planning wind ties:

- Profile used: LD 250.250.25

8. On hanger planning:

- Tendon used: Y1860S7

9. In calculating the placement of bridges:

Placement Roll:

- Cushion thickness $=12 \mathrm{~cm}$

- Roll diameter $=120 \mathrm{~cm}$

- Lip Roll Thickness $=2.5 \mathrm{~cm}$

Placement of Joints:

- Bearing thickness $\mathrm{S} 1=20 \mathrm{~cm}$

- Value $\mathrm{S} 2=7.5 \mathrm{~cm}, \mathrm{~S} 3=3 \mathrm{~cm}$,

$\mathrm{S} 4=5 \mathrm{~cm}, \mathrm{~S} 5=4 \mathrm{~cm}$

- Joint Axis Spokes:

$\mathrm{d} 1=7.5 \mathrm{~cm}, \mathrm{~d} 2=11 \mathrm{~cm}, \mathrm{~d} 3=2 \mathrm{~cm}$

\section{References}

[1] Anonim. 2005, Steel Structure Planning for RSNI T - 03 - 2005 Bridge, Bandung: National Standardization Agency
(Perencanaan Struktur Baja Untuk Jembatan RSNI T - 03 - 2005 Bandung: Badan Standarisasi Nasional).

[2] Anonim. 2016, Imposition For SNI T - 1725 - 2016 Bridge, Bandung: National Standardization Agency (Pembebanan Untuk Jembatan SNI T - 1725 - 2016 Bandung: Badan Standarisasi Nasional).

[3] Anonim. 2002, Steel Planning Procedures for Building SNI T - 1729-2002, Bandung: National Standardization Agency (Tata Cara Perencanaan Baja Untuk Gedung SNI T 1729 - 2002 Bandung: Badan Standarisasi Nasional).

[4] Anonim, 2000. Steel Structure Planning for Buildings Using the LRFD Method, Bandung Institute of Technology, InterUniversity Research Center for Engineering Sciences. (Perencanaan Struktur Baja Untuk Bangunan Gedung Menggunakan Metode LRFD, Institut Teknologi Bandung, Pusat Penelitian Antar Universitas Bidang Ilmu rekayasa).

[5] Salmon, CG. Jhonson, JE. 1992. Steel Structure Design And Behavior Volume I (Struktur Baja Desain Dan Perilaku Jilid I), Jakarta : PT. Gramedia Pustaka Utama.

[6] Setiawan, Agus. 2008. Steel Structure Planning Using LRFD Method. (Perencanaan Struktur Baja Dengan Metode LRFD). Semarang : PT Gelora Askara Pratama

[7] Stryuk, H.J. Van Deer Veen, H.K.J.W, 1995. Jembatan Terjemahan Soemargono, Jakarta : PT. Pradnya Paramita.

[8] Sunggono kh, V, Ir, 1995. Civil Engineering Book (Buku Teknik Sipil), Bandung : Penerbit Nova. 